Paideusis

\title{
Towards Teaching With an Open Heart
}

\section{Susan Walsh}

Volume 21, numéro 2, 2014

\section{Working Compassion}

URI : https://id.erudit.org/iderudit/1071562ar

DOI : https://doi.org/10.7202/1071562ar

Aller au sommaire du numéro

Éditeur(s)

Canadian Philosophy of Education Society

ISSN

0838-4517 (imprimé)

1916-0348 (numérique)

Découvrir la revue

\section{Citer cet article}

Walsh, S. (2014). Towards Teaching With an Open Heart. Paideusis, 21(2), 14-23. https://doi.org/10.7202/1071562ar

\section{Résumé de l'article}

In this paper, I explore practices for opening the heart and offering compassion towards others and also myself in the context of teaching. In doing so, I reflect upon experiences that involve the uneven distribution of "air time" in the classroom; I concentrate on such experiences because, as long-standing sources of irritation for me, I believe they can evoke insights about being present. How, for example, might I invite deeper awareness of my own being in such situations, notice how I am feeling in relation to the students, individually and collectively? How might I become better acquainted with my own resistances? Send love and compassion towards the students and also myself? Through contemplative practice, I observe my mind and habits of being. My aspiration is to teach from a softer, gentler place. I situate this work in relation to the literature in contemplative education, specifically that which offers insights into teachers' inner work. 


\title{
Towards Teaching With an Open Heart
}

\author{
SUSAN WALSH \\ Mount Saint Vincent University
}

In this paper, I explore practices for opening the heart and offering compassion towards others and also myself in the context of teaching. In doing so, I reflect upon experiences that involve the uneven distribution of "air time" in the classroom; I concentrate on such experiences because, as long-standing sources of irritation for me, I believe they can evoke insights about being present. How, for example, might I invite deeper awareness of my own being in such situations, notice how I am feeling in relation to the students, individually and collectively? How might I become better acquainted with my own resistances? Send love and compassion towards the students and also myself? Through contemplative practice, I observe my mind and habits of being. My aspiration is to teach from a softer, gentler place. I situate this work in relation to the literature in contemplative education, specifically that which offers insights into teachers' inner work.

\section{Vignette $1^{1}$}

I am listening to a student who is monopolizing the class discussion. Well, perhaps I need to consider more carefully my use of the words "listening" and "discussion." First, the class is not engaged in a discussion because a very small group of students take up the "air time" each time I pose a question. Second, I am not really listening because I am annoyed. I wonder how the rest of the class feels as these particular students talk. on and on. I don't want to be rude or disrespectful to those who are talking, but at the same time I feel that I need to change the dynamics for the benefit of all of the students. Clearly, I am not engaged with—or present to - what the speakers are saying. One part of my mind is observing myself, mindful that I am not listening and thinking how ironic this is, given my commitment to working with compassion and contemplative practices. Maybe this is not ironic after all. I am watchful, aware of what is going on. How my so-called "buttons" are being pushed. How irritated I am, how inept I feel. How I'm not feeling generous. Or open-hearted. Breathe.

As I walked home from class one evening, pondering the inequitable distribution of "air time" among students (a dynamic similar to that in the vignette above), I was stopped-literally in my tracks—by a crystal clear and deeply felt realization. Over the years as a professor at the post secondary level, I have found this uneven dynamic an ongoing issue, and I have tried a number of approaches to transform it: among these, small group work where more people can talk, candour with regard to my observations about the distribution of air time, explicit discussion of social justice perspectives in terms of whose voice is heard (and not heard), and also pre-emptive work with listening exercises. Each class is distinct and has its own particular dynamic,

\footnotetext{
${ }^{1}$ Each of the vignettes in this paper is a composite drawn from my teaching experiences at the graduate and undergraduate levels in Faculties of Education at two different universities; they do not represent specific situations.

(C) Copyright 2014. The author, Susan Walsh, assigns to Paideusis the right of first publication and educational and non-profit institutions a non-exclusive license to use this document for personal use and in courses of instruction provided that the article is used in full and this copyright statement is reproduced. Any other usage is probibited without the express permission of the author.
} 
and different approaches work differently with different groups, but, from my perspective, this issue seems to recur-and it is something I cannot seem to ignore. In that moment, as I stood on the sidewalk on the way home, I recognized my own resistance to uneven class dynamics, and how I needed to do some inner work in relation to that, rather than concentrate my energy on changing what the students were doing. How might I invite deeper awareness of my own being in such situations, notice how I am feeling in relation to the students, individually and collectively? In a context such as the one described in Vignette I (above), how might I send love and compassion towards myself (the self that feels irritated, for example) and to the students - all of them, and especially those I find aggravating? How might I create pauses or gaps in such situations to really feel what is happening within me in a compassionate and caring way? Teach from a softer, gentler, more open and compassionate place.

On that day, on that walk home, I knew in an other-than-conceptual way that I had to work on opening my heart. That the contemplative practices ${ }^{2}$ with which I have engaged for many years are calling me to be more compassionate towards myself as a teacher and, in turn, towards my students. In this paper, I thus reflect on teaching experiences that involve uneven class dynamics. I concentrate on these because, as sources of irritation, I believe they have something to teach me about being present and about opening my heart as I teach. I am also interested in the movement of compassion and gentleness, inward (toward the self) and also outward towards others and into the world-an opening that undoes (what seems like) an inner/outer separation.

I situate this work in relation to my previous research with women and difficult experiences in teaching. For more than twenty years, I have researched, analyzed, reframed, and artfully (re)presented difficult experiences, considering them in critical, theoretical, and conceptual ways as well as inviting "other" ways of knowing through poetic and creative writing, visual art, and contemplation (see, for example, Walsh, 2003, 2004, 2006, 2012; Walsh \& Brigham, 2007). I have worked with pain and fear, my own and that of others. And yet, and yet. What comes after that-or maybe along with-acknowledging, analyzing, reframing, and (re)presenting difficult experiences, painful feelings? How do we soften, rather than harden through what we perceive as difficult or uncomfortable experiences? Transform difficulty and feelings such as anger, impatience? Offer something more peaceful and good to the world? In this work, I therefore extend my previous research by writing further into particular moments of teaching through contemplative practice; examples of the latter appear in this paper as italicized passages. These sections elucidate some of the ways that I observe my mind and habits of being, work to shift them as part of my ongoing contemplative practice. Through including these italicized contemplative passages, as well as several teaching vignettes (also italicized), alongside traditional expository writing, I invite space for being and knowing in ways that can effect change; I work to actively transform my own habits of thinking, recast fear, and open the heart. In what ways might such change radiate outward?

I am sitting on the cushion, meditating, lightly bringing my attention back to the breath each time I notice thoughts arising. I sit momentarily with the out breath, rest in the gap before breathing in again. After several minutes, I begin sending loving kindness to myself, to my daughters, my partner, close family members, and then to others, especially to a colleague that I feel has wronged me and to a student that I dread seeing each week in class. I don't find this easy; in fact, it feels somewhat fake. Strangely, what feels most fake, empty even, is sending loving kindness to myself. Why is this so bard? I think about what I will eat when I get up from the cushion and wonder how many emails there are in my inbox. Breathe deeply, come back to the breath. To sending loving kindness. To feeling it. ${ }^{3}$

I have come to know that meditation practice (for me, at least) is the ground for opening my heart-and for feeling compassion towards others and myself. Where might such discussions arise in teaching and teacher education? In my reading of the literature about contemplative education, I note that many of the pieces do

\footnotetext{
${ }^{2}$ Over more than twenty-five years, I have explored contemplative practices and energy work in the form of healing circles, body work and creative movement, T'ai Chi, yoga, qi gong, and sitting meditation. Over the past five years, I have formally committed to the Shambhala Buddhist path.

3 Please see Ani Pema Chödrön's teachings on the loving kindness (maitri) practice (for example, Chödrön, 2001, pp. 119-121).
} 
not concentrate directly on the "inner work" of the teacher. The literature includes rationales for contemplative approaches to education, ${ }^{4}$ as well as research about it, ${ }^{5}$ and also implementation ideas for courses and/or programs. ${ }^{6}$ Some writers discuss contemplative approaches that the teacher might use in the classroom and comment briefly about their own contemplative practices and/or the importance of the teacher having a consistent contemplative practice. ${ }^{7}$ Stanley (2007), for example, provides insights into her own learning through her ongoing contemplative practices whereas Solloway (2000) and Miller (1994a, 1994b) focus on the teacher, her state of mind and awareness. ${ }^{8}$ The inner work of the teacher, however, is discussed more explicitly in Cohen and Bai (2007) and Siedel (2006), who delve more deeply and personally into their own thoughts and feelings. For the former, teachers are (or can be) conscious "energy workers ... awareness-workers and modellers" (Cohen \& Bai, 2007, p. 8).

Cohen and Bai (2007) begin with an informal conversation as they weave their thoughts about Dao and Zen teachers and classrooms; Seidel (2006) uses stories and reflections to highlight the challenges and difficulties of being present (mindful) as she teaches. ${ }^{9}$ Like Seidel and Cohen and Bai, I include consciously crafted textual strategies (for example, in this paper, the italicized vignettes and contemplative passages) as a way of offering glimpses into the teacher's inner work.

I am avoiding writing today. Not sure what it is that I cannot write. I put cream on the dry patches of skin on my arms. Have another piece of toast, this time with marmalade. Talk to my daughter on the phone. Give myself a somewhat stern lecture for wasting valuable writing time. What is it that I cannot get to?

I return to the cushion. Sit, breathe, notice my body. The pressure in my chest and back. The tension in my shoulders. Very quickly an insight arises. Being gentle, compassionate towards myself. Coming back to loving kindness, compassion as the needle on the compass, the resting place. True North. How does it feel?

Following the teachings of Sakyong Mipham Rinpoche (Mukpo, 2003, 2005), I frame contemplative practice ${ }^{10}$ as commitment to periods of embodied attentiveness with a focus on something in particular (for example, a

\footnotetext{
${ }^{4}$ For examples of rationales about contemplative approaches in education, please see Bai, Scott, \& Donald (2009), Miller (1994b), and Zajonc (2003, 2006).

${ }^{5}$ For examples of research in the area of contemplative education, please see Miller, (1994a), Sable (2012), and Solloway (2000).

${ }^{6}$ For examples of implementation ideas for courses and/or programs in the area of contemplative education, please see Hart (2004), Holland (2006), Kahane (2009), Rhem (2012a, 2012b), and Zajonc (2006).

7 Writers who discuss the importance of the teacher's contemplative practice include Hart (2004), Kahane (2009), and Rhem (2012); those who relate the teacher's contemplative practice to pedagogy include, for example, Bai, Scott, and Donald (2009), Cohen and Bai (2007), Falkenberg (2013), Miller (1994a, 1994b), Seidel (2006), Solloway (2000), and Stanley (2007).

8 Thich Nhat Hanh (1993) talks about the need for psychotherapists to look deeply into their own suffering and to practice deep listening and mindful speech in order for their work to be of service to others (p. 3). His teachings might well apply to teachers too. (See also comments from Elesa Commerse for yoga teachers in Steffensen, 2009).

${ }^{9}$ Cohen and Bai's (2007) piece includes images and the sounds of gongs in addition to words.

10 In this paper, I use "contemplative practice" as an overarching term that encompasses contemplation, meditation, and mindfulness. In a similar way, Miller (1994b), for example, locates meditation as "one time-honored contemplative practice" (p. 26), "a form of contemplation that involves concentrated practice" (p. 3); he frames contemplative awareness as "seeing things as they are in the here and now" (p. 2) - "nondualistic experience" (p. 3) that involves the "development of compassion" (p. 2). Spiritual leader Sakyong Mipham Rinpoche (2003, 2005) distinguishes among contemplation, meditation, and mindfulness. In contemplation, the initial object of contemplation might be a word, phrase, an image, or an idea. The instruction is to attend to the object, returning the mind to it again and again when distractions arise, and then to "let the words drop away" and rest with the "heartfelt experience" that arises (Mukpo, 2003, pp. 200-201). Meditation, in its most basic form, is a way of "train[ing] the mind" (Mukpo, 2003, p. xix) for "stability, clarity, and strength" (p. 5) through attending to the breath (see pp. 24-48; see also 2005 pp. 107-199). In teaching about meditation, the Sakyong discusses mindfulness and awareness as "tools" for training the mind (2003, p. 49); "the power of mindfulness is that we can just bring our mind back to the breath; the power of the awareness is that we know when to do it" (p. 49). Others' descriptions of mindfulness are more general, perhaps closely aligned with
} 
word, a phrase, the breath, an image, a sound). Contemplative practices move us out of the conceptual, where "conceptual" refers to cognitive processes that involve, for example, rational or logical thinking, categorization, analysis, evaluation, naming ${ }^{11}$ and into more embodied ways of knowing, those that engage, for example, the senses, ${ }^{12}$ perception, intuition and other non-linear ways of knowing. ${ }^{13}$ Miller (1994a) says that contemplation is "beyond dualism" (p. 55), "a radical openness where the individual does not try to control what is happening" (p. 56). Bai (2001) contends that mindfulness and contemplative pedagogy can help us to re-embody the world, sense/perceive it directly by backgrounding (or creating a gap in) conceptual mind—being with the world and other beings (see also Bai, Scott, \& Donald, 2009). Hart (2004) writes that

The contemplative mind is opened and activated through a wide range of approaches-from pondering to poetry to meditation - that are designed to quiet and shift the habitual chatter of the mind to cultivate a capacity for deepened awareness, concentration, and insight. Although various practices may evoke different kinds of awareness, such as creative breakthrough or compassion, they share in common a distinct non-linear consciousness that invites an inner opening of awareness. This opening within us in turn enables a corresponding opening toward the world before us. Through a fresh lens, our worldview, sense of self, and relationships may be powerfully transformed. (p. 29, my emphases)

Hart's (2004) words about the contemplative mind as an "inner opening of awareness" that "enables a corresponding opening toward the world before us" 14 resonate with what Klein says about mindfulness as a practice that "eases the sense of being caught 'inside' oneself, of being isolated from the wider world... not confined inside the body, because to go deep enough 'inside' is to touch a point that connects with a vast neither-external-nor-internal-world " (p. 85). Both Klein and Hart undo the division between inner and outer, highlighting spaciousness, dissolving divisions between self and other-opening the heart through compassion.

\section{Vignette 2}

We sit in the circle at the beginning of class. For a few weeks, I have been reflecting on how to bandle yet another situation where a few students dominate discussions. As in other such situations, I consider the individuals involved — both those who are vocal and those who are silent, or at least quiet. I decide to talk explicitly about how each of us has a responsibility to self-monitor during discussion - to listen to others and also to speak up- to consider and respect others, be mindful of the bigger picture. I feel quite grounded as I say this, willing to open a discussion about what is happening. Almost immediately, several more vocal

meditation. Klein (1995), for example, frames mindfulness as "the ability to sustain a calm, intense, and steady focus when one chooses to do so" (p. 11), and Kabat-Zinn (1994), in a more secular context, frames it as "paying attention in a particular way: on purpose, in the present moment, and non-judgmentally" (p. 4).

${ }^{11}$ See for example, Trungpa (1973, pp. 127-130, 163); see also, Bai (2001), Hart (2004), and Zajonc (2003).

${ }^{12}$ Hart (2004) notes that two forms of knowing are/have been prevalent in Western schools: rational and sensory, where rational "involves calculation, explanation, and analysis" and sensory "lives off observation and measurement" (p. 28). While I understand the way that Hart associates the sensory (as empirical) with the rational, I choose to emphasize the senses as associated with direct perception. The senses belong in both places-not an either/or dualistic view, but rather a both\&and view.

${ }^{13}$ While I am wary of setting up yet another dualism (e.g. conceptual and other-than-conceptual), I follow Irigaray (see, for example, 1985, 1996) in noting that the acknowledgement of difference, the recognition of two (on equal terms, rather than according to a hierarchical opposition) can be a strategic means of interrupting the dominance of one (in this case, the dominance of the conceptual in the dominant Western culture). Very briefly, Irigaray works to interrupt the masculine by invoking the feminine-and thus opening a productive and creative space between them (see Whitford, 1991, p. 58).

${ }^{14}$ In his article, Hart's (2004) purpose is mainly to establish a rationale and evidence for contemplative pedagogy and also to provide what he calls "a range of simple, secular methods" (p. 30) for teachers to use with students. I am using his words to highlight contemplative mind as it relates to the teacher. Though he emphasizes his focus on the student learning, Hart also notes that "a teacher who explores his or her own contemplative mind is better able to help students do the same" (p. 35). 
students seem to take offense, speak angrily. The tension in the room is palpable. Others join the conversation, and somehow we begin to explore gendered aspects of group dynamics, how particular groups of people bave been silenced socially, historically systemically. After a certain point, I decide to move the class on to other activities in order to allow some space around the tension. The discussion, however, spills over into emails and before-and-after-class conversations, both with me and among students. Some students tell me that they have never been in a class before where this issue was addressed so directly. I notice that I feel conflicted: at once willing to explicitly discuss what I see as an issue in the class and also somewhat weary, wary. A part of me wishes that things could just be comfortable, amiable. Easy.

In contemplating this situation, I realize that a part of my learning is to let go, over and over. And over. In this case, to let go of expectation, the expectation that things will be comfortable, amiable, easy when I teach. I see too that at least part of that expectation comes from a place of fear. Fear that students' anger and discomfort will adversely affect the overall class climate for the rest of the term. Worry that maybe the students will not like me at the end of the course and/or that the course evaluations will not be favourable. I am clear too that the moments of tension and conflict in classes where I have waded into uneven dynamics have made me less willing to do so again, a little more fearful, weary. I sense now fearfulness and fatigue have sometimes closed off my heart as I teach, made me less willing to be present. I am struck by how much courage it takes to be present, in the moment, open to what arises and willing to work with it in a fearless kind of way. In reflecting further upon Vignette 2, I wonder if I really was willing to be open to whatever the students might feel or say when I initiated the conversation. Further, I am clearer now that my focus was on changing the class dynamics — rather than being present to how I felt — and how I was relating to the students. Am I brave enough to relax into the gap of what is? Rest there? Suddenly, I am reminded of something that Trungpa Rinpoche (1976) said in a video about education-that educators have to become less of a nuisance to themselves and others, get out of their own (and also the students') way.

There's more. When I reflect on uneven class dynamics and wonder why they irritate me so much, I acknowledge that an early and integral aspect of my scholarly work was to explore my own experiences as a girl and woman. So, if I feel that men (for example) are taking up an inordinate amount of air time, my habit is to react, whether or not I intervene or show it externally. I remember all the times my dad encouraged my sisters and me to speak up, stand up for ourselves in our childhood and teen years, the times he tried to get us to practice arguing, his insistence that girls need to learn to do so. Even so, I was reticent to speak up in graduate classes as a student, felt that I did not have anything to worthwhile to add to the conversation, felt somehow inadequate. How is all of the above related to my irritation with uneven class dynamics? And maybe even my seemingly hard-nosed insistence that air time be more equitable? ${ }^{15}$ What does it mean to notice our habits, our usual ways of being and knowing, and also go beyond them-open our hearts? In her research with introducing meditation practice to teachers, Solloway (2000) talks about how "the use of a particular quality of attention, a practice of presence, enables the contemplative practitioner to de-condition the mind and heart" (p. 41). Trungpa Rinpoche (1973) says, "Just allowing a gap is the first stage in the practice of meditation" (p. 135), a means of interrupting habit worn ways of being in the world. Miller (1994a) notes that "during meditation practice, we compassionately witness all our thoughts and ego trips, and very gradually we begin to see that our fundamental identity is not the thoughts that form our ego structure, [and] that clear awareness is witnessing the arising and falling of all of this. This basic insight is the beginning of liberation and compassion" (p. 58). Miller's, Trungpa's, and Solloway's wise words remind me to breathe into my irritation, my fear, or whatever I am feeling in the moment as I am teaching - attend to my habit worn ways of being, my at-times closed heart-and to feel compassion towards that part of me, perhaps even articulate this to the students. Compassion, love, acceptance. (Even as I write this, I note a rankling about "acceptance," that it is somehow about giving up, not making change in explicit kinds of ways. Breathing into this too, witnessing my resistance.)

${ }^{15}$ At this point, I think it is important to acknowledge that I do feel that inequities associated with patterns of social interaction need to be explicitly discussed and critiqued. My experience shows me, however, that simply talking about it does not necessarily evoke transformation, and neither does focussing on what the students are doing. My work (in this paper and beyond) is to explore a different approach to transformation, one that begins with compassionate and caring inner work. 
A dull grey June morning after a heavy rainfall. Different birds calling, strong scent of roses. Out on the deck, I practice an open kind of meditation. A few breaths of expansiveness beyond the boundaries of self. Something like the feeling of riding my bike down a bill without the brakes. Precious seconds of freedom. Being brave, opening beart. I notice too that I am timid, able to stay open for brief seconds only, like the way I keep my hands at all times at least loosely on the brakes of my bike.

Reading Trungpa Rinpoche's teachings $(1973)^{16}$ about openness and compassion says loudly and clearly to me that we have to let go of the "self," of protecting the self, of hardening the shell around the self, of solidifying the storylines we have created, the ones that hold the stories of our egos in place. In reflecting on Vignettes 1 and 2, I now see the ways I have kept my "self" intact, the ways I have focused my attention outward to the students and on shifting the class dynamics from that vantage point, fearful of changing my habit worn ways of being and knowing in the world. My investment in feminist poststructuralist theories (see, for example, Belsey, 2002; Davies, 2000; St. Pierre, 2000; Weedon, 1997) over more than twenty years has taught me (in an intellectual way, at least) to let go of the idea of a coherent, stable, rational "self." To consider instead a subject that is shaped, reshaped though discourse, a subject that takes up different positions in different contexts. This theoretical understanding has prepared me to understand Buddhist teachings ${ }^{17}$ about the ego as a set of skandhas, ${ }^{18}$ not necessarily a coherent entity, rather, an illusion that helps us to function in the world, and something that also prevents us from being present, in the moment, open to direct (nondual) experience. And yet, I still live in the world-and teach-as though I am a coherent self much of the time, something that needs to be guarded, protected. Clearly, this is something other-thanconceptual, something that theory and analysis do not readily transform. Something connected to my contemplative practice. I remember what Kahane (2009) says about using contemplative practices in teaching his students about privilege, about compassion-that appealing to rational mind is not the way to effect transformation.

Ani Pema Chödrön's voice on the tape, ${ }^{19}$ guiding me through a practice. Breathing in heaviness, darkness, the things we think we don't want. Breathing out lightness, coolness, peace. Breathing in through all the pores of the body, breathing out through all the pores. A powerful practice, a useful image. Moving beyond the boundaries of the circumscribed self. Noticing the body, the space beyond it. Participating consciously, intentionally in an exchange of energy.

On the cushion, I breathe in my sense of inadequacy and my fearfulness. Also the disillusionment I sometimes feel. I let it all sit there; give it room. I think of others in the world who might feel this way too, and send us all love and compassion. Breathing in, breathing out. In, out.

16 The reference here is to a particular chapter in Cutting Through Spiritual Materialism (1973), "The Open Way."

${ }^{17} \mathrm{I}$ am not espousing the idea that the Buddhist teachings and poststructuralist theories agree on this (or other) points. I do feel, however, that reading and writing from a feminist poststructuralist perspective over a long period of time has allowed me to let go of the notion of a coherent rational (modernist) self, at least conceptually-which, as I note, has prepared me to let go of the illusion of such a self in more experiential ways through contemplative practices. In a more creative sense, my understanding of poststructuralist theories has informed my play with academic writing throughout my career-and served as a means of theorizing a fragmentary, changeable "self" expressed in various genres, voices, and so on.

18 In Shambhala/Buddhism, ego arises from basic primordial ground which is spacious; through a course of development, it misrecognizes itself as separate from this ground, creating form and initiating duality-the differentiation between self and other, perceiver and perceived, and so on, thus strengthening the illusion of separateness and obscuring its original state of being (Trungpa, 1973). This development_-"a mistaken belief in a 'self or "ego"' (p.123) - is explained as a series of skandhas (pp. 121-137). As the ego develops and becomes stronger, things become seemingly more fixed and solid, less spacious.

19 See Ani Pema Chodron's set of tapes, Awakening Compassion (1995). 


\section{Vignette 3}

A student (Student A) who identifies as being from a marginalized social group, frustrated by the unwillingness of his peers to see their own privilege, "calls them out" repeatedly during discussion. Some of the other students in the class are quiet, taut, hard to read. I let the ensuing silence sit. Then say sometbing about the need for us to become comfortable with silence as a place to let things be, to notice what is going on. I talk privately with the student who speaks out to see how he is feeling. Later, other students in the class ask me to put an end to the student's "outbursts," tell me that it's up to me as the professor to do something. I tell them to investigate their discomfort - and feel, on some level, that their discomfort is warranted, even important for their learning. I am clear that Student A's point of view is necessary, an important means of acknowledging and higblighting issues of privilege and also of making room for difference. I also do not want him to feel alone, more alone than he already feels in this context. And, I am simultaneously worried that the tension in the class will mean that frustration will trump learning for everyone.

What does it mean to open the heart, be compassionate in situations such as the one above?20 I note that I am willing to sit with uncomfortable silence, hold space for people to notice their feelings, talk about what's going on, and express it in different media. In Vignette 3, however, my focus was on the students' discomfort; I was willing to explore their distress. And, while I have noticed my own discomfort, have written about it in my journals, and have shared it with some students in later conversations, I am not sure that I have really sat in/with it in the moment - or that I expressed it clearly to them. In contrast, Vacarr (2001), in reflecting on a difficult moment in a class about the Holocaust, discusses her own desire for belonging within the community of the classroom and the riskiness of being vulnerable, articulates what was going on for her as she negotiated the tensions among students. She says that "neither an intellectual understanding nor a developed social skill" was adequate to prepare her for such an encounter (p. 289). Rather, her ability to witness her feelings and stay with them-be present to what arose in the moment-helped her to model vulnerability; she was thus able to stand in solidarity with students who expressed their feelings about the discussion and work towards opening things further. "The cultivation of mindful presence, which was central to [her] training," she says, "[offers much to] teachers in developing the ability to respond fully to the tension and vulnerability that often accompany moments of crisis or "teachable moments"' (p. 293). In writing this paper, I recognize more deeply that being vulnerable and open will not guarantee a peaceful or "positive" result (in the sense that students will all end up feeling comfortable). The key is to be with whatever arises, without judging it as positive, negative, or whatever, and continuing to be compassionate, open towards the self and others - and whatever arises for them. Non-judgment is a key component of compassion here.

The best and most correct way of presenting the idea of compassion is in terms of clarity, clarity which contains fundamental warmth. At this stage your meditation practice is the act of trusting in yourself. As your practice becomes more prominent in daily life activities, you begin to trust yourself and have a more compassionate attitude. Compassion in this sense is not feeling sorry for someone. It is basic warmth. As much space and clarity as there is, there is that much warmth as well, some delightful feeling of positive things happening in yourself constantly. Whatever you are doing, it is not regarded as a mechanical drag in terms of self-conscious meditation, but meditation is a delightful and spontaneous thing to do. It is the continual act of making friends with yourself. Then, having made friends with yourself, you cannot just contain that friendship within you; you must have some outlet, which is your relationship with the world. So compassion becomes a bridge to the world outside. Trust and compassion for oneself bring inspiration to dance with life, to communicate with the energies of the world. (Trungpa, 1973, pp. 97-98)

${ }^{20}$ In this particular paper, it is not my intent to discuss inclusive education or issues related to the homogeneity of the teaching profession in relation to "diverse" classes (see, for example, Berry, 2007; Dei, 2008; Sleeter, 2005; Solomona, Portelli, Daniel, \& Campbell, 2005). My intent is, rather, to highlight this situation (among others) as one with uneven dynamics and to explore my process of working with what arose. I am, however, very interested in how personal transformation is integrally and reciprocally interwoven with change at broader, more systemic levels. 
I find Trungpa Rinpoche's words inspiring and clarifying. They reinforce for me the need to be gentle and compassionate towards the self-and how the practice of doing so extends outward to others, then ripples further out into the world. In moments of irritation and fearfulness in the classroom, such as those I have described above in the vignettes about teaching, can I pause - really attend to my feelings, how I am relating to myself and others? Send friendliness, compassion towards to my irritated (and fearful) self, and also to the students, all of them? Am I brave enough to express how I am really feeling in the context of teaching? Go beyond an awareness of my feelings, be willing to share them in an honest way with the students? Am I also willing to listen to others in an open-hearted way? Such questions arise as I reflect on the teaching vignettes and notice the ways that my intention to shift class dynamics, while it included an awareness of feelings such as irritation or annoyance (as in Vignette 1) and/or the desire to stay with the students' discomfort (as in Vignette 3) also included a strong undercurrent of my own resistance to actually staying with and articulating my feelings in ways that might have invited students' openness about their own feelings. If we had had more honest and vulnerable conversations, might we have collectively shifted the dynamics?

As the italicized contemplative passages throughout this text indicate, I have been finding particular practices (such as those that Ani Pema Chödrön outlines in her 1995, 2001, and 2009 publications) to be very helpful in making this movement towards open-heartedness more concrete. When I feel hardness begin to develop toward a student in class, can I work with "compassionate abiding"-really "lean in" to the feeling on the in breath and allowing it space to be (however seemingly ugly or unacceptable), and then relaxing on the out breath, "ventilating" the feeling, "loosening the tension around it" (Chödrön, 2009, pp. 90-91). Can I create space enough to do so in situations like in Vignette 3 where I was unwilling to really listen to the students who were uncomfortable with Student A's "outbursts"? Be brave enough to stay with what is in a non-judgemental kind of way in the service effecting wider shifts in my interactions with others?

In class these days, I notice that I feel more relaxed. Can see the humour in what is going on. I watch my irritation with students who talk over others and send them compassion. Notice how they are "pushing my buttons," and send myself compassion too. With time, I see more clearly that many of the students in the class are quite self-aware. Those who are quiet write or talk about this, as do those who are more vocal. Some students indicate their thoughts about the class dynamics. I soften and know from a place deep inside that we all need space and kindness, appreciation rather than impatience in order to learn, to transform things. With practice, this is becoming something more than a conceptual understanding for me.

\section{References}

Bai, H. (2001). Beyond the educated mind: Toward a pedagogy of mindfulness. In B. Hocking \& J. Haskell \& W. Linds (Eds.), Unfolding bodymind: Exploring possibility through education (pp. 89-99). Brandon VT: Foundation for Educational Renewal.

Bai, H., Scott, C., \& Donald, B. (2009). Contemplative pedagogy and revitalization of teacher education. Alberta Journal of Educational Research, 55(3), 319-334.

Belsey, C. (2002). Poststructuralism: A very short introduction. Oxford: Oxford University Press.

Berry, K. (2007). Exploring the authority of whiteness in education: An auto-ethnographic journey. In, P. Carr \& D. Lund (Eds.), The Great White North?: Exploring whiteness, privilege and identity in education (pp. 1932). Rotterdam: Sense Publishers.

Canadian Race Relations Foundation (2009). CRRF's response to the concluding observations of the CERD. Retrieved August 12, 2009 at http://www.crr.ca/content/view/242/376/lang, french/\#visible

Chödrön, P. (1995). (Audiotapes). Awakening compassion: Meditation practice for difficult times. Boulder CO: Sounds True.

Chödrön, P. (2001). Tonglen: The path of transformation. T. Ötro (Ed.). Halifax NS: Vajradhatu Publications.

Chödrön, P. (2009). Taking the leap: Freeing ourselves from old habits and fears. S. Boucher (Ed.). Boston: Shambhala Publications.

Cohen, A., \& Bai, H. (2007). Dao and Zen of teaching: Classroom as enlightenment field. Educational Insights, 11(3). Accessed February 23, 2011 at http://www.ccfi.educ.ubc.ca/publication/insights/v11n03/articles/bai.html 
Davies, B. (2000). A body of writing: 1990-1999. New York: AltaMira Press.

Dei, G. S. (2008). Schooling as community: Race, schooling, and the education of African youth. Journal of Black Studies, 38(3), 346-366.

Falkenberg, T. (2013). Teaching as contemplative professional practice. Paideusis, 20(2), 25-35.

Hanh, T. N. (1993). The fourth precept: Deep listening and loving speech. Accessed October 26, 2011 at http://dharma.ncf.ca/introduction/precepts/precept-4.html

Hart, T. (2004). Opening the contemplative mind in the classroom. Journal of Transformative Education, 2(21), 28-46.

Holland, D. (2006). Contemplative practice in unexpected places: Teaching mindfulness in Arkansas and Australia. Teachers College Record, 108(9), 1842-1861.

Irigaray, L. (1985). This sex which is not one. Ithaca, New York: Cornell University Press.

Irigaray, L. (1996). I love to you: Sketch for felicity within history (A. Martin, Trans.). New York: Routledge.

Kabat-Zinn, J. (1994). Wherever you go, there you are: Mindfulness meditation in everyday life. New York: Hyperion.

Kahane, D. (2009). Learning about obligation, compassion, and global justice: The place of contemplative pedagogy. New Directions for Teaching and Learning, 118, 49-60. DOI: 10.1002/tl.352

Klein, A. C. (1995). Meeting the Great Bliss Queen: Buddhists, feminists, and the art of the self. Boston: Beacon Press.

Miller, J. (1994a). Contemplative practice in higher education: An experiment in teacher education. Journal of Humanistic Psychology, 34(4), 53-69.

Miller, J. (1994b). The contemplative practitioner: Meditation in education and the professions. Toronto: OISE Press.

Mukpo, M. (Sakyong Mipham). (2003). Turning the mind into an ally. New York: Riverhead Books.

Mukpo, M. (Sakyong Mipham). (2005). Ruling your world: Ancient strategies for modern life. Toronto: Doubleday.

Rhem, J. (2012). Contemplative pedagogy, Part 1. National Teaching and Learning Forum, 21(3), 1-6.

Rhem, J. (2012). Contemplative pedagogy, Part 2. National Teaching and Learning Forum, 21(4), 1-5.

Sable, D. (2012). The impacts of reflective practices on the dispositions for critical thinking in undergraduate courses. (Doctoral dissertation, Dalhousie University). Retrieved from http://dalspace.library.dal.ca/handle/10222/15464

Seidel, J. (2006). Some thoughts on teaching as contemplative practice. Teachers College Record, 108(9), 19011914.

Sleeter, C. (2005). How white teachers construct race. In, C. McCarthy, W. Critchlow, G. Dimitriadis, \& N. Dolby (Eds.). Race, identity and representation in education (2nd Ed.) (pp. 243-256). New York: Routledge.

Solloway, S. (2000). Contemplative practitioners: Presence or the project of thinking gaze differently. Encounter: Education for meaning and social justice, 13(3), 30-42.

Solomona, R. P., Portelli, J.P., Daniel, J., \& Campbell, A. (2005). The discourse of denial: How white teacher candidates construct race, racism and 'white privilege.' Race Ethnicity and Education, 8(2) 147-169. DOI: $10.1080 / 13613320500110519$

St. Pierre, E. (2000). Poststructural feminism in education: An overview. Qualitative Studies in Education, 13(5), 477-515.

Stanley, C. (2007). Mindfulness for educators. Insight Journal, 28(Summer), 26-29.

Steffensen, S. (2009). Elesa Commerse: Helping others find their way through breast cancer. YogaChicago, 16(5). Accessed August 28, 2011 at http://www.yogachicago.com/sep09/teacher.shtml

Trungpa, C. (1973). Cutting through spiritual materialism. J. Baker \& M. Casper (Eds.). London: Shambhala.

Trungpa, C. (1976). (Videorecording). The myth of education. Talk given at Naropa University. Boulder $\mathrm{CO}$.

Vacarr, B. (2001). Moving beyond polite correctness: Practicing mindfulness in the diverse classroom. Harvard Educational Review, 71(2), 285-295.

Walsh, S. (2003). Experiences of fear and pain in teaching: A collaborative arts-based inquiry. In A. Clarke \& G. Erickson (Eds.). Teacher inquiry: Living the research in everyday practice (pp. 164-178). London: RoutledgeFalmer.

Walsh, S. (2004). Being homeless: Female subjectivity and difference. Journal of the Canadian Association for Curriculum Studies, 2(1), 113-143. Accessed August 5, 2012 at https://pi.library.yorku.ca/ojs/index.php/jcacs/issue/view/713/showToc 
Walsh, S. (2006). An Irigarayan framework and resymbolization in an arts-informed research process. Qualitative Inquiry, 12(5), 976-993.

Walsh, S. (2012). Contemplation, artful writing: Research with internationally educated female teachers. Qualitative Inquiry, 18(3), 265-276. DOI 10.1177/1077800411431553

Walsh, S. \& Brigham, S. (2007). Internationally educated female teachers who have immigrated to Nova Scotia: A research/performance text. International Journal of Qualitative Methods, 6(3), 1-28. Accessed August 11, 2009 at http:// ejournals.library.ualberta.ca/index.php/IJQM/issue/view/34

Weedon, C. (1997). Feminist practice and poststructuralist theory (2nd Ed.). Malden, Massachusetts: Blackwell Publishers.

Whitford, M. (1991). Luce Irigaray: Philosophy in the feminine. New York: Routledge.

Zajonc, A. (2003). Spirituality in higher education: Overcoming the divide. Liberal education, 89(1), 50-58.

Zajonc, A. (2006). Love and knowledge: Recovering the heart of learning through contemplation. Teachers College Record, 108(9), 1742-1759.

\section{About the Author}

Susan Walsh is an associate professor in the Faculty of Education at Mount Saint Vincent University and also a member of the leadership team for $W$ aves of Compassion in Halifax Regional Municipality. She teaches courses in research, literacy education, gender and literacy, and drama in education. Her research interests include: female teachers-their subjectivities and experiences (women and difficult experiences in teaching; internationally educated female teachers), feminist poststructuralist theory, innovative forms of research (artsbased research, writing as a process of inquiry, poetic inquiry, memory work/collective biography), contemplative inquiry and pedagogy, and embodied and relational ways of being and knowing. She has presented and published her work widely: for example, in Qualitative Inquiry, Qualitative Studies in Education (QSE), and Teaching and Teacher Education. Email: susan.walsh@msvu.ca Website: http://www.msvu.ca/en/home/programsdepartments/education/facultyresearch/drsusanwalsh.aspx 